\title{
Identification and treatment of viral hepatitis $C$ in persons who use drugs: a prospective, multicenter outreach study in Flanders, Belgium
}

Dana Busschots ${ }^{1,2^{*}} \mathbb{0}$, Cécile Kremer ${ }^{3}$, Rob Bielen ${ }^{1,2}$, Özgür Muhammet Koc ${ }^{1,2,4}$, Leen Heyens ${ }^{1,2,4}$, Eefje Dercon ${ }^{5}$, Rita Verrando ${ }^{5}$, Tessa Windelinckx ${ }^{6,7}$, Griet Maertens ${ }^{6}$, Stefan Bourgeois ${ }^{8}$, Niel Hens ${ }^{3,9}$, Catharina Mathei ${ }^{6,10}$ and Geert Robaeys ${ }^{1,2,11}$

\begin{abstract}
Background: Targeted screening for hepatitis $\mathrm{C}$ viral (HCV) infection is not yet widely executed in Belgium. When performed in people who use drugs (PWUD), it is mainly focused on those receiving opiate agonist therapy (OAT). We wanted to reach out to a population of difficult to reach PWUD not on centralized OAT, using non-invasive screening as a bridge to re-integration in medical care supported by facilitated referral to a specialist.
\end{abstract}

Methods: This was a prospective, multicenter cohort study in PWUD not enrolled in a centralized OAT program in a community-based facility in Limburg or OAT program in a community-based facility in Antwerp, Belgium, from October 2018 until October 2019. Two study teams recruited participants using an outreach method at 18 different locations. Participants were tested for HCV antibodies (Ab) by finger prick, and risk factors were assessed through a face-to-face questionnaire. Univariate analyses were used to assess the association between HCV Ab and each risk factor separately. A generalized linear mixed model was used to investigate the association between the different risk factors and HCV.

Results: In total, 425 PWUD were reached with a mean age of $41.6 \pm 10.8$, and $78.8 \%$ (335/425) were men. HCV Ab prevalence was 14.8\% (63/425). Fifty-six (88.9\%) PWUD were referred, of whom 37 (66.1\%) were linked to care and tested for HCV RNA. Twenty-nine (78.4\%) had a chronic HCV infection. Treatment was initiated in 17 (58.6\%) patients. The adjusted odds for HCV Ab were highest in those with unstable housing 6 months before inclusion $(p<.001$, AOR $8.2 \mathrm{Cl} 95 \% 3.2-23.3)$ and in those who had ever shared paraphernalia for intravenous drug use $(p<.001, \mathrm{AOR} 6.2 \mathrm{Cl}$ 95\% 2.5-16.0).

Conclusions: An important part tested positive for HCV. Treatment could be started in more than half of the chronically infected referred and tested positive for HCV-RNA. Micro-elimination is necessary to achieve the World Health Organization goals by 2030. However, it remains crucial to screen and link a broader group of PWUD to care than to focus solely on those who inject drugs.

Trial registration: clinicaltrials.gov NCT04363411, Registered 27 April 2020—Retrospectively registered. https://clinicaltr ials.gov/ct2/show/NCT04363411?term =NCT04363411\&draw=2\&rank=1

Keywords: Hepatitis C virus, Outreach, People who use drugs, Linkage to care, High-income country

*Correspondence: dana.busschots@uhasselt.be

${ }^{1}$ Faculty of Medicine and Life Sciences, Hasselt University, Martelarenlaan

42, 3500 Hasselt, Diepenbeek, Belgium

Full list of author information is available at the end of the article

(c) The Author(s) 2021. Open Access This article is licensed under a Creative Commons Attribution 4.0 International License, which permits use, sharing, adaptation, distribution and reproduction in any medium or format, as long as you give appropriate credit to the original author(s) and the source, provide a link to the Creative Commons licence, and indicate if changes were made. The images or other third party material in this article are included in the article's Creative Commons licence, unless indicated otherwise in a credit line to the material. If material is not included in the article's Creative Commons licence and your intended use is not permitted by statutory regulation or exceeds the permitted use, you will need to obtain permission directly from the copyright holder. To view a copy of this licence, visit http://creativecommons.org/licenses/by/4.0/. The Creative Commons Public Domain Dedication waiver (http://creativeco mmons.org/publicdomain/zero/1.0/) applies to the data made available in this article, unless otherwise stated in a credit line to the data. 


\section{Background}

The majority of chronic liver disease and liver-related deaths worldwide are caused by viral hepatitis infections $[1,2]$. Concerning hepatitis $\mathrm{C}$ viral infections (HCV), the World Health Organization (WHO) has set targets to eliminate $\mathrm{HCV}$ by reducing new infections by $90 \%$ and mortality by $65 \%$ in $2030[1,3]$. The prevalence of chronic $\mathrm{HCV}$ infection was estimated to be $0.12 \%$ among the general Belgian population in 2019 and is generally low $(<0.6 \%)$ in high-income countries [4-6]. Nonetheless, in high-risk populations such as people who use drugs (PWUD), HCV prevalence is increased [7]. In Ireland and Madrid (Spain), 50\% and 33\% of the PWUD were exposed to an HCV infection [8,9]. A recent study estimated the $\mathrm{HCV}$ antibody $(\mathrm{Ab})$ prevalence in Belgian people injecting drugs (PWID), a subpopulation of PWUD, at $41.1 \%$ [10]. However, no data on $\mathrm{HCV}$ Ab prevalence in the more general PWUD population are available for Belgium [11].

With direct-acting antiviral therapy and its $\geq 95 \%$ cure rate, $\mathrm{HCV}$ elimination is achievable $[12,13]$. Between 2015 and 2017, direct-acting antiviral (DAA) treatment was only reimbursed if fibrosis was staged $\geq$ F3 in Belgium [14]. As of January 2017, the reimbursement criteria have been adjusted to $\geq F 2$. Unlimited access has only been possible since 2019 [15, 16]. However, DAA treatment can only be prescribed and initiated by a hepatologist and is available only in hospital pharmacies.

A Belgian 'Hepatitis C Plan' was developed in 2014 with the purpose to (1) reduce transmission, (2) increase the number of HCV-positive patients aware of their diagnosis, and (3) enhance the patient care pathway and quality of life [17]. However, to date, all efforts remain dependent on local initiatives and no strategy is implemented at a national level.

In Belgium, both NGO Free Clinic Antwerp and the zorGGroep Zin Limburg are community-based facilities specialized in addiction care and closely involved in HCV care for PWUD $[11,18]$. They provide HCV care to PWUD enrolled in their drug services, opiate agonist treatment (OAT) program and/or needle syringe programs (NSP). However, young injectors who have not yet contacted these centers, former PWUD, stimulants injectors, and opioid users receiving OAT at their local pharmacy are often not reached [18]. Providing HCV care to these specific high-risk subgroups, who are at the heart of the epidemic, is challenging [3]. There are no good estimates of the size of these subgroups in Europe, which are often completely isolated from care. Nevertheless, outreach methods to contact vulnerable populations have been proven successful in different European countries and Australia [19-23]. We aimed to reach out to this specific and vulnerable PWUD community not reached within the OAT program of a community-based facility using a non-invasive screening method. Determining the prevalence of $\mathrm{HCV}$ Ab could give us a better idea of the current challenges concerning $\mathrm{HCV}$ among this difficultto-reach high-risk group in a high-income country.

\section{Methods \\ Study setting}

The NGO Free Clinic in Antwerp and the zorGGroep Zin Limburg are community-based facilities for addiction care. Free Clinic is located in the city of Antwerp and zorGGroep Zin has several locations in the province of Limburg. Harm reduction such as OAT and NSP is offered in these centers in a very low-threshold manner. Clients can obtain OAT in two different ways at these centers. On the one hand, there is the on-site provision (centralized OAT) where the medication is taken at the center under supervision. On the other hand, a client may obtain a prescription from the attending physician to receive the medication from a local pharmacist.

Both centers offer $\mathrm{HCV}$ care (e.g., education and screening, extra support) to their clients.

All clients of the Free Clinic are offered and reached for annual HCV screening. Therefore, only individuals who were not registered at the MSOC (medical social center) Free Clinic were included in this study.

The zorGGroep Zin also offers a yearly HCV screening to all its clients. Clients on central provision are easily reached. However, previous research at zorGGroep Zin showed that clients who only receive an OAT prescription and receive their medication at the pharmacy are difficult to reach and are often not tested (data not shown). Therefore, this study only included individuals who were not registered at zorGGroep Zin or clients of zorGGroep Zin who only received their prescription at the center resulting in them not being reached for $\mathrm{HCV}$ care.

\section{Study design \\ Sample}

This is a prospective, multicenter cohort study in PWUD. Participants were eligible for inclusion if they were aged 18 years or older, not enrolled in a centralized OAT program in Limburg or any OAT program in Antwerp from October 2018 until October 2019. PWUD were defined as people who have a history of drug use or who actively use drugs (excluding alcohol).

\section{Intervention}

The team in Antwerp consisted of a HCV reference nurse accompanied by a social worker, an addiction care physician, and peer workers. In Limburg, the team consisted of an HCV case manager nurse accompanied by a Ph.D. student and a medical Ph.D. student. The two teams 
recruited participants using the same outreach method by organizing screening events in 18 different locations across the city of Antwerp, the Kempen region, and the province of Limburg. The events' locations were always communicated in advance, using posters and flyers to inform possible candidates. Locations existed of homeless shelters, local pharmacies involved in OAT care and NSP, addiction care centers not providing (centralized) $\mathrm{OAT}$, and public locations (e.g., public squares, night shelters, low-threshold facilities of civil society organizations). The screening events were always organized in cooperation with peers, general physicians, the addiction care centers, and the Public Centre for Social Welfare. In the province of Limburg, the study team used a mobile home in several locations.

Participants were tested for $\mathrm{HCV} \mathrm{Ab}$ by finger prick using OraQuick ${ }^{\circledR}$. While waiting for the rapid test results (15 min), an encoded questionnaire on paper was filled out face-to-face in a private and secure setting. After completing the questionnaire and finalizing the tests, the participant was provided with a ten euro remuneration for participating in the study. Every participant was informed about all aspects of the disease, from the transmission to treatment. Additionally, if the test was positive, the study team took ample time to report the diagnosis and discuss it in detail and an appointment at the hepatology department was planned immediately. If the PWUD claimed to have been treated in the past, the research team contacted the specialist. If the specialist confirmed a successful treatment and a permanent HCV sustained virologic response without ongoing risk behavior, the PWUD was not referred further. In case of referral and when requested, the nurse and/or a peer accompanied the PWUD to the specialist's appointment. During the screening, a telephone number or email address was requested from each PWUD who tested positive for a finger prick test. This telephone number (phone call/text) or email address was used to remind the PWUD at least three times of the appointment with the specialist in the hospital. Loss to follow-up (LTFU) was defined as loss of contact with the PWUD despite at least three contact attempts. Follow-up data after a positive finger prick test were retrospectively collected after 6 months. The data were collected by the nurses of both research teams based on pre-defined questionnaires.

The study was approved by the Ethical Committee of Ziekenhuis Oost-Limburg and Hasselt University $(18 / 0052 \mathrm{U})$. The study protocol is registered at clinicaltrials.gov (NCT04363411). The study was conducted in accordance with the provisions of the Declaration of Helsinki and its amendments. Good clinical practice guidelines were followed throughout the study, and all participants provided written informed consent [24].

\section{Questionnaire}

The questionnaire was available in Dutch, French, and English and covered a total of 22 questions. Data from the questionnaire included birth gender, year of birth that was categorized into:<1955, 1955-1974, and $>1974$ based on the European baby-boom cohort [25], source of income, level of education, housing past 6 months, ever have been incarcerated, alcohol abuse ( $>14$ units women or $>21$ units men per week), age of first drug use, kind of drugs (ever, past 6 months), manner of drug use, frequency of drug use (past 6 months), kind of intravenous (IV) drugs (ever, past 6 months), frequency of IV drug use (past 6 months), sharing IVrelated paraphernalia (ever, past 6 months) receiving OAT, connected to an NSP.

Follow-up data included: METAVIR score, the result of HCV RNA viral load, the HCV genotype, initiation of treatment, and the reason for not initiating treatment. METAVIR score is used to grade fibrosis in patients with HCV ranging from no fibrosis $(F 0)$ to cirrhosis $(F 4)$ [26]. Cut-off values for $\mathrm{HCV}$ as measured by FibroScan ${ }^{\circledR}$ are $F 0-F 1=<7.2 \mathrm{kPa}, F 2=7.2-9.5 \mathrm{kPa}, F 3=9.5-12.5 \mathrm{kPa}$, $F 4=>12.5 \mathrm{kPa}[27]$.

\section{Endpoints of the study}

This study's primary objective was to assess the HCV Ab prevalence using a rapid test in a high risk, difficult to reach subgroup of PWUD in Flanders, Belgium. Measuring the prevalence could give us a better impression of the current challenges concerning HCV in these PWUD. The secondary objective was to evaluate the linkage to care of PWUD who tested positive for HCV Ab.

\section{Statistical analyses}

Patient demographics were summarized using mean \pm standard deviation for continuous characteristics and by proportions for categorical characteristics. To assess differences in participant characteristics between the trial sites, the Chi-squared test or Fisher's exact test was used for categorical variables and independent-samples $t$ test for continuous variables.

Univariate models were used to assess the association for each risk factor separately. Risk factors associated $(p<0.150)$ with HCV Ab in these univariate analyses were included as fixed effects in a multiple GLMM. To account for heterogeneity between individuals from the different trial sites (Antwerp as urban and Limburg as mixed urban-rural), a generalized linear mixed model (GLMM) was used to investigate the association between the different risk factors and HCV Ab. In these models, the trial site was then included as a random intercept. 


\section{Sample size}

The ideal sample size for a prevalence study is a function of the expected prevalence and precision for a given confidence level [28]. For a small prevalence, as is the case for $\mathrm{HCV} \mathrm{Ab,} \mathrm{a} \mathrm{conservative} \mathrm{choice} \mathrm{for} \mathrm{the} \mathrm{amount} \mathrm{of} \mathrm{preci-}$ sion has to be made using one-fifth of the estimated prevalence (for the effect size) [29].

In this study, an estimated HCV Ab prevalence of $30 \%$ was used. This is less than the estimated prevalence of HCV Ab in PWID [10, 11], but we chose this conservative estimate, as we also included non-PWID. With a confidence interval (CI) of $95 \%, z$ is $1.96 . P$ is 0.30 and $d=0.30 / 5=0.06$ (the formula is provided in [see Additional file 1]), where $z$ is the quantile of the normal distribution corresponding to the level of confidence, $P$ is the expected prevalence, and $d$ is the effect size (i.e., the maximum difference between estimated and true prevalence). Therefore, an inclusion of 224 PWUD was necessary. However, since the prevalence will be estimated in a study using data from two sites (cluster design), the design factor was taken into account [30]. Therefore, the sample size was multiplied by a factor of 1.5 [30]. A total of at least 336 PWUD had to be included.

\section{Results}

Between October 2018 and October 2019, 36 screening days at 18 different locations were organized. In total, 425 PWUD not connected to any OAT in Antwerp or the centralized OAT program in Limburg were reached. The socio-demographic characteristics of the study population are shown in Table 1 . The population of Antwerp and Limburg did not differ in terms of age at inclusion ( $42.1 \pm 10.7$ vs. $41.0 \pm 11.0, p=0.280)$, gender (male: $81.2 \%$ vs. $76.6 \%, p=0.270$ ), age of first drug use $(18.4 \pm 8.0$ vs. $18.3 \pm 8.3, p=0.906)$, ever injected drugs (yes: $32.9 \%$ vs. $36.7 \%, p=0.394$ ), or enrolment in an OAT program not linked to the center in Antwerp or the centralized program in Limburg (100\% vs. 96.3\%, $p=0.137)$. Therefore, the results of both locations are analyzed together.

\section{Prevalence HCV Ab}

Sixty-three (14.8\%) PWUD tested positive for HCV Ab using a finger prick test. Of them, 26 (41.2\%) were unaware that they had ever been in contact with HCV and might have been infected. Looking only at the PWID in this population, 58/148 (39.2\%) was HCV Ab positive.

\section{Risk factors associated with HCV Ab positivity}

The unadjusted odds for HCV Ab were highest in those who had injected in the past 6 months before inclusion $(p<0.001$, OR 31.3 CI 95\% 14.1-77.5). Persons who were
Table 1 Baseline characteristics of the study population

\begin{tabular}{|c|c|}
\hline Characteristics $(n=425)$ & $N(\%)$ \\
\hline Age (years) mean $\pm S D$ (range) & $41.6 \pm 10.8$ \\
\hline Gender (male) & $335(78.8)$ \\
\hline \multicolumn{2}{|l|}{ Country of birth } \\
\hline Belgium & $333(78.4)$ \\
\hline Other & $91(21.4)$ \\
\hline Missing & $1(0.2)$ \\
\hline \multicolumn{2}{|l|}{ Source of income last 6 months } \\
\hline Employment & $87(20.5)$ \\
\hline Welfare check & $254(59.8)$ \\
\hline Pension & $13(3.1)$ \\
\hline None & $68(16.0)$ \\
\hline Missing & $3(0.7)$ \\
\hline \multicolumn{2}{|l|}{ Housing last 6 months } \\
\hline At home (owned/rented) & $225(52.9)$ \\
\hline Residential/family/friends & $122(28.7)$ \\
\hline Prison/homeless & $78(18.4)$ \\
\hline Missing & $2(0.5)$ \\
\hline \multicolumn{2}{|l|}{ Level of education } \\
\hline Primary school (7-12 years) & $22(5.2)$ \\
\hline Partly completed high school (<16 years) & $130(30.6)$ \\
\hline Completed high school (18 years) & $206(48.4)$ \\
\hline Higher education (> 18 years) & $66(15.5)$ \\
\hline Missing & $1(0.2)$ \\
\hline Ever have been incarcerated (yes) & $227(53.4)$ \\
\hline \multicolumn{2}{|l|}{ Alcohol abuse } \\
\hline Active $(<6 \mathrm{~m})$ & $122(28.7)$ \\
\hline Former & $126(29.6)$ \\
\hline Never & $175(41.2)$ \\
\hline Missing & $2(0.5)$ \\
\hline Age of first drug use (years) mean \pm SD (range) & $18 \pm 8.1$ \\
\hline Ever IV drug use (yes) & $148(34.8)$ \\
\hline Recent $(<6 \mathrm{~m})$ IDU $(n=148)$ & $73(49.3)$ \\
\hline Recently $(<6 \mathrm{~m})$ injected not connected to NSP $(n=73)$ & $13(17.8)$ \\
\hline Recently $(<6$ m) used opioid not connected to OAT $(n=97)$ & $47(48.5)$ \\
\hline
\end{tabular}

IV intravenous, OAT opiate agonist therapy, NSP needle syringe program

part- or full-time employed had a significantly lower odds of $\mathrm{HCV} \mathrm{Ab}$ positivity compared to those that were unemployed ( $p=0.014$, OR 4.8 CI 95\% 1.4-18.6) or received an allowance $(p=0.006$, OR 4.5 CI 95\% 1.7-15.3). The results of the univariate GLMM are provided in an additional file [see Additional file 2].

The random intercept variance for the trial site was estimated to be 0 , indicating no difference between the trial sites in HCV Ab positivity. This was also shown in univariate analyses using a Chi-squared test $(p=0.063)$.

The adjusted odds ratio (AOR) for $\mathrm{HCV}$ increased significantly in PWUD (Table 2), who spent the last 
Table 2 Results of the multiple generalized linear mixed models

\begin{tabular}{|c|c|c|c|}
\hline Risk factor & Estimate (SE) & $p$ value & $\operatorname{AOR}(95 \% \mathrm{Cl})$ \\
\hline (Intercept) & $-4.122(0.450)$ & & \\
\hline \multicolumn{4}{|l|}{ Housing last $6 \mathrm{~m}$} \\
\hline Owned/rented & (Ref) & (Ref) & \\
\hline Residential/family/friends & $0.686(0.486)$ & .159 & $1.985(0.759-5.193$ \\
\hline Prison/homeless & $2.115(0.506)$ & $<.001$ & $8.201(3.164-23.306)$ \\
\hline \multicolumn{4}{|l|}{ Sharing paraphernalia } \\
\hline Never & (Ref) & (Ref) & \\
\hline Ever & $1.830(0.470)$ & $<.001$ & $6.231(2.514-16.042)$ \\
\hline Last 6 months & $-0.948(0.700)$ & .175 & $0.388(0.094-1.477)$ \\
\hline Drug use last $6 \mathrm{~m}$-cocaine & $-1.406(0.501)$ & .005 & $0.245(0.088-0.626)$ \\
\hline Drug use last 6 m—heroin & $1.333(0.441)$ & .010 & $3.105(1.317-7.464)$ \\
\hline IV drug use ever-heroin & $1.635(0.486)$ & .001 & $5.127(2.004-13.572)$ \\
\hline IV drug use last $6 \mathrm{~m}$-amphetamines & $1.524(0.492)$ & .002 & $4.593(1.753-12.219)$ \\
\hline IV drug use last 6 m—cocaine & $1.597(0.619)$ & .010 & $4.939(1.515-17.370)$ \\
\hline
\end{tabular}

The $\mathbf{p}$-values indicated in bold are significant values

$A O R$ adjusted odds ratio, $\mathrm{Cl}$ confidence interval, $I V$ intravenous, ref reference

6 months before inclusion in prison or were homeless $(p<0.001$, AOR 8.2 CI 95\% 3.2-23.3), who had ever shared paraphernalia for IV drug use $(p<0.001$, AOR 6.2 CI 95\% 2.5-16.0), who had used heroin in the last 6 months $(p=0.010$, AOR $3.1 \mathrm{CI} 95 \% 1.3-7.5)$, who had ever injected heroin $(p=0.001$, AOR $5.1 \mathrm{CI}$ 95\% 2.0-13.6), who had injected amphetamines in the last 6 months $(p=0.002$, AOR 4.6 CI 95\% 1.8-12.2), or injected cocaine in the last 6 months $(p=0.010$, AOR 4.9 CI 95\% 1.5-17.4). On the other hand, having used cocaine in the last 6 months in general significantly decreased the odds of HCV $(p=0.005$, AOR 0.2 CI $95 \%$ 0.1-0.6).

\section{Linkage to care and treatment for HCV}

Of the 63 PWUD who tested positive for HCV Ab using a finger prick test, seven (11.1\%) had been successfully treated in the past and had not reported any risk factors since. They were therefore not referred to the specialist for further examinations. Of the remaining 56 PWUD, 37 (66.1\%) were linked to care and tested by venipuncture for HCV RNA (Fig. 1), of whom 29 (78.4\%) were found to have a chronic $\mathrm{HCV}$ infection. FibroScan ${ }^{\circledR}$ scores were available for $24(85.8 \%)$ patients. METAVIR scores of $F 0-F 1, F 2, F 3$, and $F 4$ were found in, respectively, seven (29.2\%), seven (29.2\%), four (16.7\%), and six (20.7\%) persons. Genotypes were determined for 28 PWUD. Seven (25.0\%) had genotype 1a, three (10.7\%) genotype $1 \mathrm{~b}$, one (3.6\%) genotype $2 \mathrm{~b}, 15$ (53.6\%) genotype 3 , and two (7.1\%) genotype 4. Treatment was started in 17 (58.6\%) of the $29 \mathrm{HCV}$ RNA positives. Of those who had not yet started, one patient was unwilling, one was too unstable

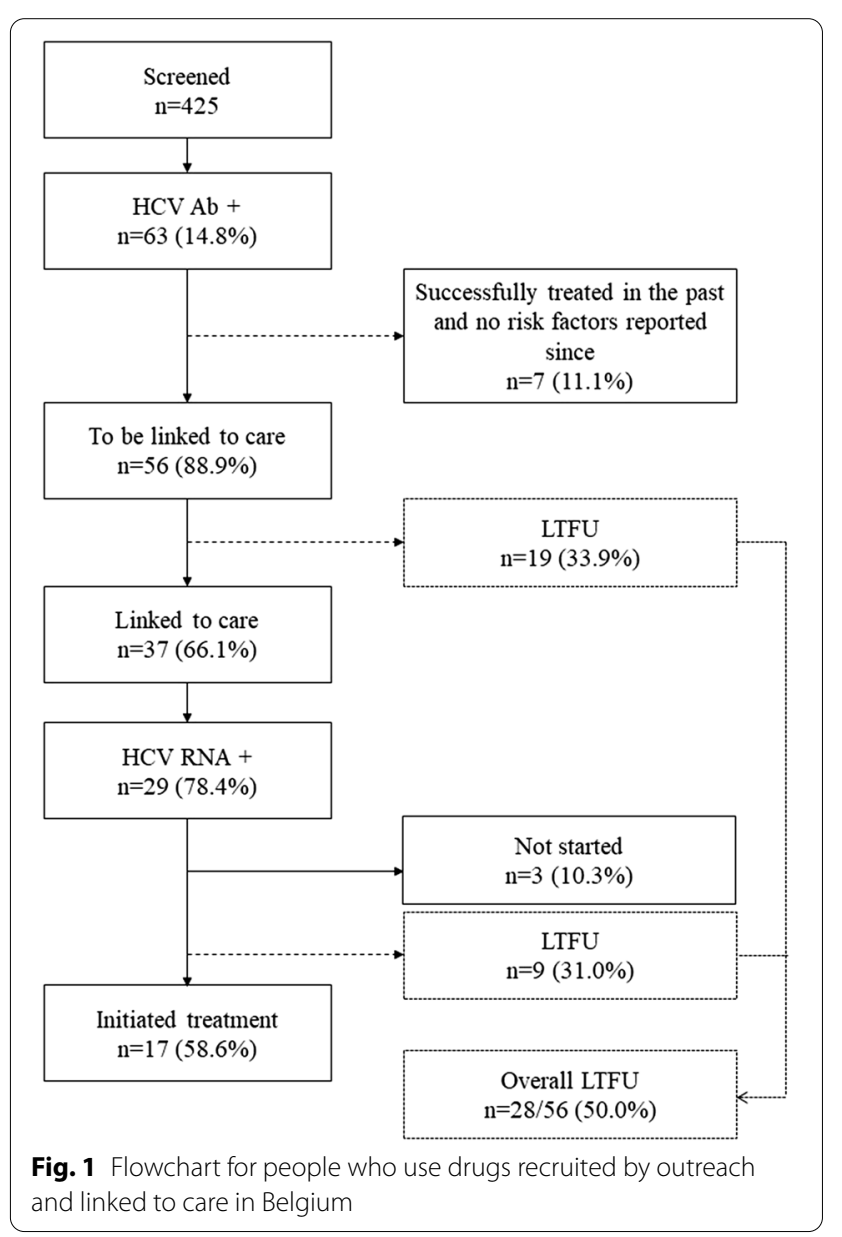


according to the physician, one was taken to prison after screening, and nine were LTFU. Of those who were LTFU, five out of nine had a METAVIR score of F2 or higher, and five stated to have injected drugs in the last 6 months before screening. Overall, we reported a LTFU of $28 / 56$ (50.0\%, Fig. 1).

\section{Discussion}

With this large group of PWUD not connected to the OAT program of the center for addiction care in Antwerp or the centralized OAT program of the center in Limburg, this study exceeded the preset sample size. The threshold to be tested was minimal as a non-invasive finger prick was used to test $\mathrm{HCV} \mathrm{Ab}$. This is very important as a large part of this population has difficult venous access. An important part of the study group tested positive for $\mathrm{HCV} \mathrm{Ab} \mathrm{(14.8 \% ).} \mathrm{Of} \mathrm{these} \mathrm{HCV} \mathrm{Ab} \mathrm{positives,}$ $41.2 \%$ were unaware that they had ever been in contact with HCV and might have been infected. Our data, therefore, support the elimination of $\mathrm{HCV}$ in Europe by substantiating the scientific evidence that not all PWUD are reached through OAT programs, and alternative initiatives need to be implemented to reach these groups [31].

The HCV Ab prevalence in our cohort (14.8\%) was many times higher than in the general Belgian population (0.12\%) [5]. If we only focus on the PWID in our population, the prevalence is comparable to a Belgian study in PWID and high-risk opiate users (39.2\% vs.41.1\%) [10]. Looking at the entire screened cohort, $6 \%$ were not aware of potential exposure to $\mathrm{HCV}$ infection. This is an important finding and contributes to the 'Belgian Hepatitis $\mathrm{C}$ plan.' One of the action points is to increase the number of HCV-positive patients aware of their diagnosis [32]. Moreover, this finding stresses the importance of screening, not only to identify new cases but also to identify previously known cases and link them back to the cascade of care.

In our study, unstable housing (incarcerated/homeless) last 6 months before inclusion increased HCV risk. Prisoners are more likely to engage in HCV-related risk behavior such as unsterile tattooing, high-risk sexual behavior, and sharing paraphernalia [33, 34]. Worldwide, this has led to an increased prevalence of $\mathrm{HCV}$ in prisoners compared to the general population. A review concerning $\mathrm{HCV}$ in American homeless people shows an $\mathrm{HCV} \mathrm{Ab}$ prevalence ranging from 23 to 39\% [35]. In a study by Barror et al. [19] in high-risk populations (community addiction, homeless, and prison services) in Ireland, the UK, Romania, and Spain, an HCV Ab prevalence of $37.0 \%$ was found. This is slightly higher than our findings and can be explained by the fact that in the study of Barror et al. [19], the proportion that ever injected drugs was higher $(44.6 \%)$ than in our study population (34.8\%).

As expected, HCV odds were increased for those who had ever injected heroin or had injected amphetamines or cocaine in the past 6 months. Moreover, we found a high percentage of people who had injected drugs in the last 6 months. Almost half (49\%) of the PWID in our study stated to have injected in the past 6 months before inclusion.

In Belgium, all PWUD can have access to NSP and low threshold OAT even outside an addiction care center (e.g., local pharmacy). Almost 20\% of the recent injectors in our study were not connected to NSP, and almost half of the recent opioid users were not connected to an OAT program. These people were informed about NSP and OAT and provided with practical information about the addiction care centers. Studies have shown that OAT is associated with a $50 \%$ reduction in the risk of an $\mathrm{HCV}$ infection [36]. European studies even show a reduction of $54 \%$ in $\mathrm{HCV}$ infection risk associated with high NSP coverage [36]. By testing those with ongoing risk factors and informing them, and linking them to harm reduction programs, we can potentially prevent new acute infections. Only one factor seemed to decrease the odds of $\mathrm{HCV}$ infection. People who had used cocaine in general in the last 6 months before inclusion showed a significantly lower risk. Although this type of use is not identified as a risk factor in our study, we are aware that sniffing can cause nasal wounds that can lead to HCV transmission when sharing unsterile and contaminated material.

In our study and many others, IV drug use is the most significant risk factor for $\mathrm{HCV}$. Nevertheless, it remains crucial to screen a broader group of PWUD involving not only injecting but also stimulant users. On the one hand, this avoids stigmatizing a subpopulation. On the other hand, if only PWID had been tested in this study, 5/63 (7.9\%) PWUD with a potential infection would not have been detected for further follow-up. Moreover, not all PWUD will want or dare to identify themselves as PWID.

To increase the uptake of screening, each participant was provided a ten euro remuneration for participating in the study. International studies show that cash incentives increase the linkage to care and treatment [37, 38]. Despite the effort, linkage to care in this study was lower than expected. A total of $66.1 \%$ of PWUD were linked to care. Nevertheless, our findings on linkage to care are in line with Barror et al. [19], in which linkage to care ranged from 64 to $89 \%$ in those who were referred after a positive HCV RNA test on scene. A study by Poll et al. [39] shows that the main reasons for missing an appointment are priority to buy drugs, the cost of travel, or the appointment's timing. In our study, treatment was 
initiated in just over half of those linked to care and eligible for treatment. The most common cause for not initiating treatment was the LTFU of the patient. All LTFU patients were active PWID, and $56.0 \%$ had stated that they had injected in the 6 months before inclusion. This is a problematic finding because, globally, active PWID form the current heart of the infection. This population should be treated as a priority to contain this epidemic. Multiple methods were used to find and reconnect these PWID. Although all LTFU-PWID in our study were without a trace, we could not confirm the main reason for not initiating treatment. In the past, the strict reimbursement criteria for receiving treatment were probably one of the main causes of LTFU in this population. However, since January 2019, the reimbursement criteria have been adjusted, and every infected person is eligible for treatment despite their degree of fibrosis in Belgium [40, 41]. Besides, five out of nine LTFU had a fibrosis score $\geq$ F2 and could have been treated in 2018. Additionally, we lack the ability to provide on-site treatment in Belgium. Treatment can only be prescribed and initiated by a hepatologist and is only available in hospital pharmacies, which means that on-site treatment is currently not possible in Belgium. Access to treatment would improve, and patients would receive their medication more easily if treatment could be prescribed by other healthcare professionals and be available in local pharmacies, resulting in less LTFU.

This study has several limitations. During the screening events, participants were only screened for $\mathrm{HCV}$ $\mathrm{Ab}$ by rapid test. However, an HCV RNA test is necessary to confirm an infection. HCV RNA testing by finger prick using a point of care molecular testing instrument is currently not approved as a diagnostic tool. However, the instrument has recently been validated in a population of Belgian PWUD [42]. Therefore, we were unable to make a diagnosis on scene. Moreover, this may have led to an increased dropout rate because the PWUD had to move to the hospital without the certainty that they were infected. Furthermore, before January 2019, the main reason for not starting treatment was probably Belgium's strict reimbursement criteria. Since January 2019, the lack of the possibility to offer on-site treatment seems to be the leading cause of not starting treatment. As a result, many PWUD disappear after screening and never reach the hospital for their specialist appointment. In order to proceed to on-site treatment in Belgium, discussions at ministerial level are inevitable. Further, although convenience sampling was used in this study, participants were recruited at different locations to reach a wide range of PWUD and limit selection bias. However, even though we have tried to avoid selection bias as much as possible, it can never be avoided entirely. For example, extremely high-risk PWUD, especially PWID, may not have been included in our study. These results should not be generalized to the entire PWUD population. Finally, the data were derived by means of a face-to-face questionnaire that could have led to a social desirability bias. This could have led to an underreporting of IV drug use. Nevertheless, the PWUD population and more specific the PWIDs are the most important group to find, test, diagnose, and (re-)connect to (low-threshold) health care as they are the heart of the $\mathrm{HCV}$ epidemic.

\section{Conclusions}

We were able to screen a group of hard-to-reach PWUD, and although Belgium is a country with low-threshold access to addiction care (e.g., local pharmacy), not everyone was linked to addiction care. An important part of the study group tested positive for $\mathrm{HCV} \mathrm{Ab}$. In more than half of the chronically infected, treatment could be started. This study provides critical local data on the current epidemic in a high-income country and could be valuable for other regions with similar epidemiological and healthcare systems. Micro-elimination is necessary to achieve the WHO goals, but it remains critical to screen and inform a broader group of PWUD involving not only injecting but also stimulant users. Also, it is essential to actively seek out high-risk groups that remain under the radar of primary care, as demonstrated in this study. If we want to achieve the WHO goals by 2030 in Belgium, we urgently need a nationally implemented screening and treatment strategy that preferably allows for testing with point of care HCV RNA testing, fibrosis staging (mobile FibroScan ${ }^{\circledR}$ ), and on-site treatment.

\section{Abbreviations}

HCV: Hepatitis C virus; WHO: World Health Organization; PWUD: People who use drugs; Ab: Antibody; PWID: People who inject drugs; OAT: Opioid agonist treatment; NSP: Needle syringe program; LTFU: Lost to follow-up; IV: Intravenous; GLMM: Generalized linear mixed model; Cl: Confidence interval; OR: Odds ratio; AOR: Adjusted odds ratio.

\section{Supplementary Information}

The online version contains supplementary material available at https://doi. org/10.1186/s12954-021-00502-7.

Additional file 1. A1. Formula for sample size calculation.

Additional file 2. . A2. Univariate generalized linear mixed models to investigate the association between different risk factors and hepatitis $C$ antibodies.

\section{Acknowledgements}

The Ph.D. authors of this review are part of the Limburg Clinical Research Center (LCRC), supported by the foundation Limburg Sterk Merk, province of Limburg, Flemish government, Hasselt University, Ziekenhuis Oost-Limburg and Jessa Hospital. D.B., C.K, N.H., and G.R. are part of the project G0B2317N funded by the Fund of Scientific Research-Flanders (FWO). 


\section{Authors' contributions}

D.B., R.B., and G.R. designed the study. D.B., R.B., E.D., G.M., and T.W. collected the data. C.K. and N.H. conducted the statistical analyses. D.B. drafted the first version of the paper. All co-authors critically revised the article and approved the final version, including the authorship list. All authors read and approved the final manuscript.

\section{Funding}

This project has been made possible thanks to an unrestricted grant by Gilead Sciences (V-2330) and AbbVie (V-2656) registered at Hasselt University. No direct benefits were granted to the pharmaceutical industry.

\section{Availability of data and materials}

The data supporting the conclusions of this article are included within the article and its additional files.

\section{Declarations}

\section{Ethics approval and consent to participate}

The study was approved by the Ethical Committee of Ziekenhuis OostLimburg and Hasselt University (18/0052U). The study protocol is registered at clinicaltrials.gov (NCT04363411). The study was conducted in accordance with the provisions of the Declaration of Helsinki and its amendments. Good clinical practice guidelines were followed throughout the study and all participants provided written informed consent.

\section{Consent for publication}

Not applicable.

\section{Competing interests}

D.B. has received travel grants from AbbVie and Gilead Sciences and research grants from Gilead; R.B. has received travel grants from AbbVie, Gilead Sciences, and MSD and research grants from Gilead and MSD; Ö.K. has received a travel grant and research grants from Gilead and CyTuVax BV; N.H. has received grants from GlaxoSmithKline (GSK), grants from Johnson \& Johnson pharmaceuticals and grants from Pfizer; C.M has received travel grants from Gilead, MSD Belgium, and INDIVIOR and has acted as consultant for MSD Belgium; G.R. has received research grants from AbbVie, Janssen Pharmaceuticals, MSD, and has acted as a consultant/advisor for AbbVie, BMS, Gilead Sciences, and MSD. All other co-authors report no competing interests.

\section{Author details}

${ }^{1}$ Faculty of Medicine and Life Sciences, Hasselt University, Martelarenlaan 42, 3500 Hasselt, Diepenbeek, Belgium. ${ }^{2}$ Department of Gastroenterology and Hepatology, Ziekenhuis Oost-Limburg, Genk, Belgium. ${ }^{3}$ Interuniversity Institute for Biostatistics and Statistical Bioinformatics (I-Biostat), Data Science Institute, Hasselt University, Diepenbeek, Belgium. ${ }^{4}$ School of NUTRIM, Maastricht University Medical Centre, Maastricht, The Netherlands. ${ }^{5}$ zorGGroep Zin Limburg, Hasselt, Belgium. ${ }^{6}$ Free Clinic Ngo, Antwerp, Belgium. ${ }^{7}$ Harm Reduction, Coordinator GIG - Health promotion in Injecting Drug use Flanders, Flanders, Belgium. ${ }^{8}$ Department of Gastroenterology, ZNA Antwerp, Antwerp, Belgium. ${ }^{9}$ Centre for Health Economic Research and Modelling Infectious Diseases, Vaccine and Infectious Disease Institute, University of Antwerp, Antwerp, Belgium. ${ }^{10}$ Department of Public Health and Primary Care, KU Leuven, Leuven, Belgium. ${ }^{11}$ Department of Gastroenterology and Hepatology, University Hospitals KU Leuven, Leuven, Belgium.

\section{Received: 30 November 2020 Accepted: 9 May 2021}

Published online: 17 May 2021

\section{References}

1. WHO: Global Hepatitis Report, 2017. In: Edited by Organization WH. Geneva; 2017.

2. WHO: Progress report on access to hepatitis $C$ treatment: focus on overcoming barriers in low- and middle-income countries. In. Geneva: World Health Organization; 2018 .

3. WHO: Global health sector strategy on viral hepatitis 2016-2021. In: Edited by Organization WH, vol. WHO/HIV/2016.06. Geneva; 2016.
4. Nelson PK, Mathers BM, Cowie B, Hagan H, Des Jarlais D, Horyniak D, Degenhardt L. Global epidemiology of hepatitis B and hepatitis $C$ in people who inject drugs: results of systematic reviews. Lancet (Lond Engl). 2011;378(9791):571-83

5. Litzroth A, Suin V, Wyndham-Thomas C, Quoilin S, Muyldermans G, Vanwolleghem T, Kabamba-Mukadi B, Verburgh V, Jacques M, Van Gucht $\mathrm{S}$, et al. Low hepatitis C prevalence in Belgium: implications for treatment reimbursement and scale up. BMC Public Health. 2019;19(1):39.

6. Muyldermans G, Van Gucht S, Van Baelen L. Jaarrapport 2016: hepatitis C virus; Wetenschappelijk Instituut Volksgezondheid-Institution Scientifique de santé Publique (WIV-ISP). https://nrchm.wiv-isp.be/nl/ ref_centra_labo/hepatitis/Rapporten/Rapport\%20HCV\%202016.pdf. Accessed 15 Sept 2020.

7. World Health Organisation: Fact sheet n164 Hepatitis C. In: WHO; Updated July 2015.

8. Crowley D, Murtagh R, Cullen W, Lambert JS, McHugh T, Van Hout MC. Hepatitis $C$ virus infection in Irish drug users and prisoners-a scoping review. BMC Infect Dis. 2019;19(1):702.

9. Valencia La Rosa J, Ryan P, Alvaro-Meca A, Troya J, Cuevas G, Gutiérrez J, Moreno S. HCV seroconversion in a cohort of people who use drugs followed in a mobile harm reduction unit in Madrid: Breaking barriers for HCV elimination. PLoS ONE. 2018;13(10):e0204795.

10. Van Baelen L, Plettinckx E, Antoine J, Gremeaux L. Prevalence of HCV among people who inject drugs in Brussels-a respondent-driven sampling survey. Harm Reduct J. 2020;17(1):11.

11. Mathei C, Robaeys G, van Damme P, Buntinx F, Verrando R. Prevalence of hepatitis $C$ in drug users in Flanders: determinants and geographic differences. Epidemiol Infect. 2005;133(1):127-36.

12. Marshall AD, Cunningham EB, Nielsen S, Aghemo A, Alho H, Backmund M, Bruggmann P, Dalgard O, Seguin-Devaux C, Flisiak R, et al. Restrictions for reimbursement of interferon-free direct-acting antiviral drugs for $\mathrm{HCV}$ infection in Europe. Lancet Gastroenterol Hepatol. 2018;3(2):125-33.

13. Marshall AD, Pawlotsky JM, Lazarus JV, Aghemo A, Dore GJ, Grebely J. The removal of DAA restrictions in Europe-one step closer to eliminating HCV as a major public health threat. J Hepatol. 2018;69:1188-96.

14. Recente informatie januari 2015: tapentadol, alemtuzumab, simeprevir en sofosbuvir, levothyroxine (L-thyroxine ${ }^{\circledR}$ ). http://www.bcfi.be/nl/articles/ 2271 ?folia $=2270$. Accessed 15 Sept 2020.

15. Antivirale geneesmiddelen tegen hepatitis $C$ : vergoedingsvoorwaarden vanaf 1 januari 2019. https://www.riziv.fgov.be/nl/themas/kost-terugbetal ing/door-ziekenfonds/geneesmiddel-gezondheidsproduct/terugbetal en/specialiteiten/wijzigingen/Paginas/antivirale-hepatitisc-terugbetal ingsvoorwaarden_20190101.aspx. Accessed 15 Sept 2020.

16. Antivirale geneesmiddelen tegen hepatitis $C$ : vergoedingsvoorwaarden vanaf 1 januari 2017. https://www.inami.fgov.be/nl/themas/kost-terug betaling/door-ziekenfonds/geneesmiddel-gezondheidsproduct/terug betalen/specialiteiten/wijzigingen/Paginas/antiretrovirale_hepatitisc_ terugbetalingsvoorwaarden_20170101.aspx. Accessed 15 Sept 2020.

17. Federale Overheidsdienst Volksgezondheid VvdveL: Belgisch staatsbladMoniteur Belge: Protocolakkoord 'HCV-plan'. In: Brussels; 08.08.2014: 57926-57940.

18. Bielen R, Verrando R, Penders J, Oris E, Nevens F, Robaeys G. Case management to improve uptake for screening and therapy of hepatitis $C$ viral infection in people who inject drugs. In: AALSD. Boston; 2016.

19. Barror S, Avramovic G, Oprea C, Surey J, Story A, Macias J, Cullen W, Crowley D, Horan A, Naughton AM, et al. HepCare Europe: a service innovation project. HepCheck: enhancing HCV identification and linkage to care for vulnerable populations through intensified outreach screening. A prospective multisite feasibility study. J Antimicrob Chemother. 2019;74(Supplement_5):v39-46.

20. Lampejo T, Turner R, Roberts C, Allen K, Watson L, Caverley-Frost L, Scott P Ostridge E, Cooney G, Hardy J, et al. Novel outreach settings to enhance sexually transmitted infection/HIV awareness, diagnosis and treatment in hard-to-reach populations. Int J STD AIDS. 2018;29(3):266-72.

21. Coupland H, White B, Bates A, Park JN, Iversen J, Maher L. Engaging people who inject drugs in hepatitis $C$ virus testing and prevention through community-based outreach, in Sydney, Australia. Drug Alcohol Rev. 2019;38(2):177-84

22. Delile JM, de Ledinghen $V$, Jauffret-Roustide $M$, Roux P, Reiller B, Foucher J, Dhumeaux D. Hepatitis $C$ virus prevention and care for drug injectors: the French approach. Hepatol Med Policy. 2018;3(7):1-9. 
23. Stagg HR, Surey J, Francis M, MacLellan J, Foster GR, Charlett A, Abubakar I. Improving engagement with healthcare in hepatitis $C$ : a randomised controlled trial of a peer support intervention. BMC Med. 2019;17(1):71.

24. International Conference of Harmonization (ICH). ICH Tripartite Guideline for Good Clinical Practices E6 (R1), June 10; 1996. http://www.ich.org/filea dmin/Public_Web_Site/ICH_Products/Guidelines/Efficacy/E6/E6_R1_ Guideline.pdf. Accessed 22 Sept 2020.

25. Bielen R, Kremer C, Koc OM, Busschots D, Hendrickx DM, Vanelderen P, Hens N, Nevens F, Robaeys G. Screening for hepatitis $C$ at the emergency department: should babyboomers also be screened in Belgium? Liver Int. 2018;39(4):667-75.

26. Bedossa P, Poynard T. An algorithm for the grading of activity in chronic hepatitis C. The METAVIR Cooperative Study Group. Hepatology (Baltimore, MD). 1996;24(2):289-93.

27. Quantifying fibrosis with FibroScan. https://www.echosens.com/en/ myfibroscan-smart-app-to-manage-chronic-liver-diseases. Accessed 15 Jan 2021

28. Arya R, Antonisamy B, Kumar S. Sample size estimation in prevalence studies. Indian J Pediatr. 2012;79(11):1482-8.

29. Pourhoseingholi MA, Vahedi M, Rahimzadeh M. Sample size calculation in medical studies. Gastroenterol Hepatol Bed Bench. 2013;6(1):14-7.

30. Rutterford C, Copas A, Eldridge S. Methods for sample size determination in cluster randomized trials. Int J Epidemiol. 2015. https://doi.org/10. 1093/ije/dyv113.

31. European Monitoring Centre for Drugs and Drug Addiction: Hepatitis C among drug users in Europe: epidemiology, treatment and prevention. In: Hickman M, Martin N (eds) Insights, vol 23. Lisbon: EMCDDA; 2016.

32. Federale Overheidsdienst Volksgezondheid VvdveL: Belgisch staatsblad-Moniteur Belge: Protocolakkoord 'HCV-plan'. In: Brussels; 2014: 57926-57940.

33. Bielen R, Stumo SR, Halford R, Werling K, Reic T, Stover H, Robaeys G, Lazarus JV. Harm reduction and viral hepatitis C in European prisons: a cross-sectional survey of 25 countries. Harm Reduct J. 2018;15(1):25.

34. Dolan K, Wirtz AL, Moazen B, Ndeffo-Mbah M, Galvani A, Kinner SA, Courtney R, McKee M, Amon JJ, Maher L, et al. Global burden of HIV, viral hepatitis, and tuberculosis in prisoners and detainees. Lancet (Lond Engl). 2016;388(10049):1089-102.
35. Chack E, Talal AH, Sherman KE, Schiff ER, Saab S. Hepatitis C virus infection in USA: an estimate of true prevalence. Liver Int. 2011;31(8):1090-101.

36. Platt $L$, Minozzi $S$, Reed J, Vickerman $P$, Hagan $H$, French $C$, Jordan $A$, Degenhardt L, Hope V, Hutchinson S, et al. Needle syringe programmes and opioid substitution therapy for preventing hepatitis $C$ transmission in people who inject drugs. Cochrane Database Syst Rev. 2017;9:Cd012021.

37. Norton B, Bachhuber M, Singh R, Agyemang L, Arnsten J, Cunningham C, Litwin A. Evaluation of contingency management as a strategy to improve HCV linkage to care and treatment in persons attending needle and syringe programs: a pilot study. Int J Drug Policy. 2019;69:1-7.

38. Sulkowski M, Ward K, Falade-Nwulia O, Moon J, Sutcliffe C, Brinkley S, Haselhuhn T, Thomas D, Katz S, Herne K, et al. Randomized controlled trial of cash incentives or peer mentors to improve HCV linkage and treatment among HIV/HCV coinfected persons who inject drugs: the CHAMPS Study. J Hepatol. 2017;66(1):S719.

39. Poll R, Allmark P, Tod AM. Reasons for missed appointments with a hepatitis C outreach clinic: a qualitative study. Int J Drug Policy. 2017;39:130-7.

40. Antivirale geneesmiddelen tegen hepatitis $C$ : vergoedingsvoorwaarden vanaf 1 januari 2017. http://www.riziv.fgov.be/nl/themas/kost-terugbetal ing/door-ziekenfonds/geneesmiddel-gezondheidsproduct/terugbetal en/specialiteiten/wijzigingen/Paginas/antiretrovirale_hepatitisc_terug betalingsvoorwaarden_20170101.aspx\#.Ww0_40iFNPY. Accessed 22 Sept 2020.

41. RIZIV: Antivirale geneesmiddelen tegen hepatitis C: vergoedingsvoorwaarden vanaf 1 januari 2019. In: RIZIV; 2018.

42. Bielen R, Koc OM, Busschots D, Verrando R, Nevens F, Robaeys G. Validation of hepatitis $C$ virus RNA detection using capillary blood by fingerprick (GenXpert system)- Hepatitis C fingerprick study. J Viral Hepat. 2020;27:709-14.

\section{Publisher's Note}

Springer Nature remains neutral with regard to jurisdictional claims in published maps and institutional affiliations.
Ready to submit your research? Choose BMC and benefit from:

- fast, convenient online submission

- thorough peer review by experienced researchers in your field

- rapid publication on acceptance

- support for research data, including large and complex data types

- gold Open Access which fosters wider collaboration and increased citations

- maximum visibility for your research: over 100M website views per year

At BMC, research is always in progress.

Learn more biomedcentral.com/submissions 